\title{
AECU-489
}

UN I TED STA TES A TOM I C ENERGY COMMISS I ON

\section{HEMOGLOBIN LABELED BY RADIOACTIVE LYSINE}

\author{
by \\ W. F. Bale \\ C. L. Yuile \\ I. DeLaVergne \\ I. I. Miller \\ G. H. Whipple
}

University of Rochester

This document contains no restricted data as defined by the Atomic Energy Act of 1946.

This copy is reproduced direct from copy as submitted to this office.

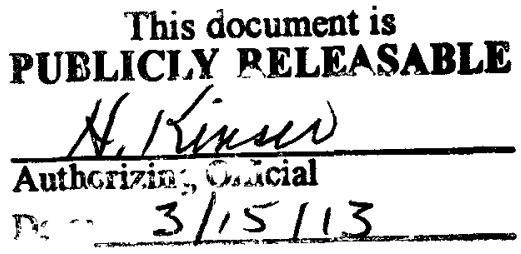

Technical Information Division, Oak Ridge, Tennessee AEC, Oak Ridge, Tenn., 12-8-49--468-A12088

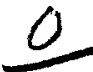




\section{DISCLAIMER}

This report was prepared as an account of work sponsored by an agency of the United States Government. Neither the United States Government nor any agency Thereof, nor any of their employees, makes any warranty, express or implied, or assumes any legal liability or responsibility for the accuracy, completeness, or usefulness of any information, apparatus, product, or process disclosed, or represents that its use would not infringe privately owned rights. Reference herein to any specific commercial product, process, or service by trade name, trademark, manufacturer, or otherwise does not necessarily constitute or imply its endorsement, recommendation, or favoring by the United States Government or any agency thereof. The views and opinions of authors expressed herein do not necessarily state or reflect those of the United States Government or any agency thereof. 


\section{DISCLAIMER}

Portions of this document may be illegible in electronic image products. Images are produced from the best available original document. 
HEMOGLOBIN LABELED BY RADIOACTIVE LYSI NE

ה. F, Bale, C. L. Yuile, L. DeLaVergne, I. L. Miller, and G. H. Whipple

This paper reports on the utilization of the tagged epsilon carbon of DL-lysine by a dog both anemic and hypoproteinemic due to repeated bleeding plus a diet low in protein. The experiment extended over a period of 234 days, a time sufficient to indicate an erythrocyte Iife span of at least 115 ciays based upon the rate of replacement of labeled red cell proteins. The proteins of broken down red cells seem not to be used with any great preference for the synthesis of new hemoglobin.

\section{EXPERIMENTAL PROTOCOL}

Dog 44-10 a mongrel, adult, male collie. On a regime of repeated blood withdrawl plus a low protein diet the blood hematocrit was reduced froin a normal 54.7 to a value of 37.3 per cent over a period of one month imnediately preceding the start of this experiment. Plasma protein concentration fell from 6.75 to $4.71 \mathrm{gm}$. per $100 \mathrm{ml}$. plasma. Weight fell from 15.5 to 13 kilos.

The dog was given, by mouth, mixed with 100 gm. of hamburg, $0.58 \mathrm{gm}$. of DL-1ysine which contained 15 microcuries $\mathrm{c}^{14}$ in the epsilon carbon position. The lysine synthesis had been carried out as described by Helmkamp and co-workers (7). The dog took this feeding eagerly. After 4.5 hours a feeding of $400 \mathrm{gm}$. of the basal diet low protein biscuits was supplemented with an additional $50 \mathrm{gm}$. of hamburg. The dog received da1ly for the next 3 days $400 \mathrm{gm}$. of biscuits plus $100 \mathrm{gm}$. hamburg. The dog was then returned to a standard kennel diet adequate for the rapid regeneration of plasma and blood cell proteins. Under this regime the red cell hematocrit rose to 48 per cent in 2 weeks and 52 per cent at the end of 5 weeks. Plasma proteins rose from $4.71 \mathrm{gm}$. to $5.9 \mathrm{gm}$. per $100 \mathrm{ml}$. in 5 weeks. 
Blood samples of about $15 \mathrm{ml}$. each were withdrawn and mixed with $0.1 \mathrm{ml}$. of saturated sodium citrate at times indicated by the points on Fig. 1 and Fig. 2. The blood samples were centrifuged to separate plasma and the cells then washed twice with normal saline. No effort was made to separate erythrocytes from other centrifugable, formed elements of this blood. One gram portions of dehydrated blood cells and the dried solids from about $7 \mathrm{ml}$. of plasma were used for individual $\mathrm{c}^{14}$ measurements. The carbon of such samples was converted to $\mathrm{CO}_{2}$ by a wet oxidation and introduced into an ionization chamber of $1200 \mathrm{ml}$. volume. The volume of evolved $\mathrm{CO}_{2}$ was determined. Ionization current measurements were made with a dynamic condenser electrometer (1). Quantitative urine collections were made with a metabolism cage and aliquot portions were analyzed for $\mathrm{c}^{14}$. Single radioactivity determinations were made for plasma and urine. Blood cell $\mathrm{C}^{14}$ analyses were mostly done in duplicate, intervals of about two months separating the duplicate determinations. The duplicate analyses gave reasonably corresponding results. The greatest difference found between duplicates was 18 per cent, the average difference, 5 per cent. The data for blood cells presented are an average of duplicate values.

\section{EXPERIMENTAL FESULTS}

The urine specimen removed from the metabolism cage 8 hours after the administration of labeled lysine contained 27.8 per cent of tho administered $\mathrm{C}^{14}$. Total $\mathrm{C}^{14}$ recovery from urine up to 72 hours totalled 34.9 per cent.

Figure 1 shows concentrations of $\mathrm{c}^{14}$ per gm. of plasma carbon and per $\mathrm{gm}$. of blood cell carbon following the feeding of labeled lysine. Experiments reported in detail in the accompanying paper (5) indicate that the plasma $c^{14}$ values for periods of 24 hours and longer after labeled 
lysine feeding represent predominantly radioactive carbon incorporated in plasma proteins.

The droo in $\mathrm{c}^{14}$ concentration per gm. carbon in the blood cells

(Fig. 1) in the 10 to 35 day period represents predominantly a dilution of labeled cells with new cells which the dog is able to form as the result of an adequate diet.

Figure 2 shows the total incorporation of $c^{14}$ in circulating cells and circulating plasma. The shape of curve shown is very similar to that resulting if the concentrations of $\mathrm{c}^{14}$ in the colls and plasme of a unit quantity of blood are plotted as a furction of time. In computing the curves of Fig. 2 plasma values are based upon experimentally obtained plasme volumes. The value of circulating cells is estimated as 82 per cent of the value directly calculated from hematocrit and plasma volume determinations $(2,3)$. No direct data were obtained concerning the chemical form of the $\mathrm{C}^{14}$ incorpnrated in the blood cells of this dog. In a rat the erythrocyte $\mathrm{C}^{14}$ following feeding of this tagged lysine was found almost exclusively in the globin portion of the isolated hemoglobin molecule.

Blood loss through sampling over the 234 days of this experiment represents about one-third of the dog's calculated $1000 \mathrm{ml}$. blood volume. No correction for this loss is made in computing the data for Fig. 1 and Fig. 2 .

\section{DISCUSSION}

Figures 1 and 2 demonstrate that this dog, depleted of both hemoglobin and plasma proteins, utilized the epsilon carbon of lysine with less lag in building plasma proteins than in building blood cells. Figure 2 shows that there is a turnover or utilization of newly formed plasma proteins as represented by a drop in $\mathrm{C}^{14}$ content even under conditions 
4

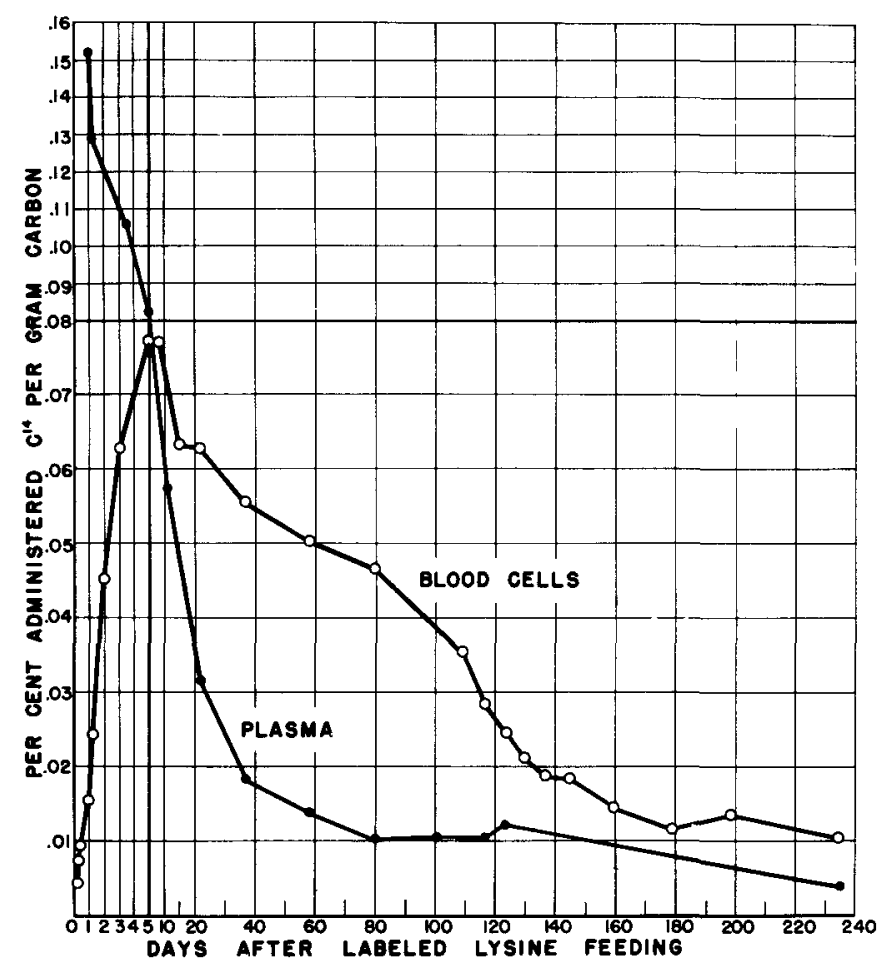

F1g. 1. Concentration of $c^{1 / 4}$ in plasma and blood cell carbon following the foeding of labeled lysine to an anemia and hypoproteinemic dog. 


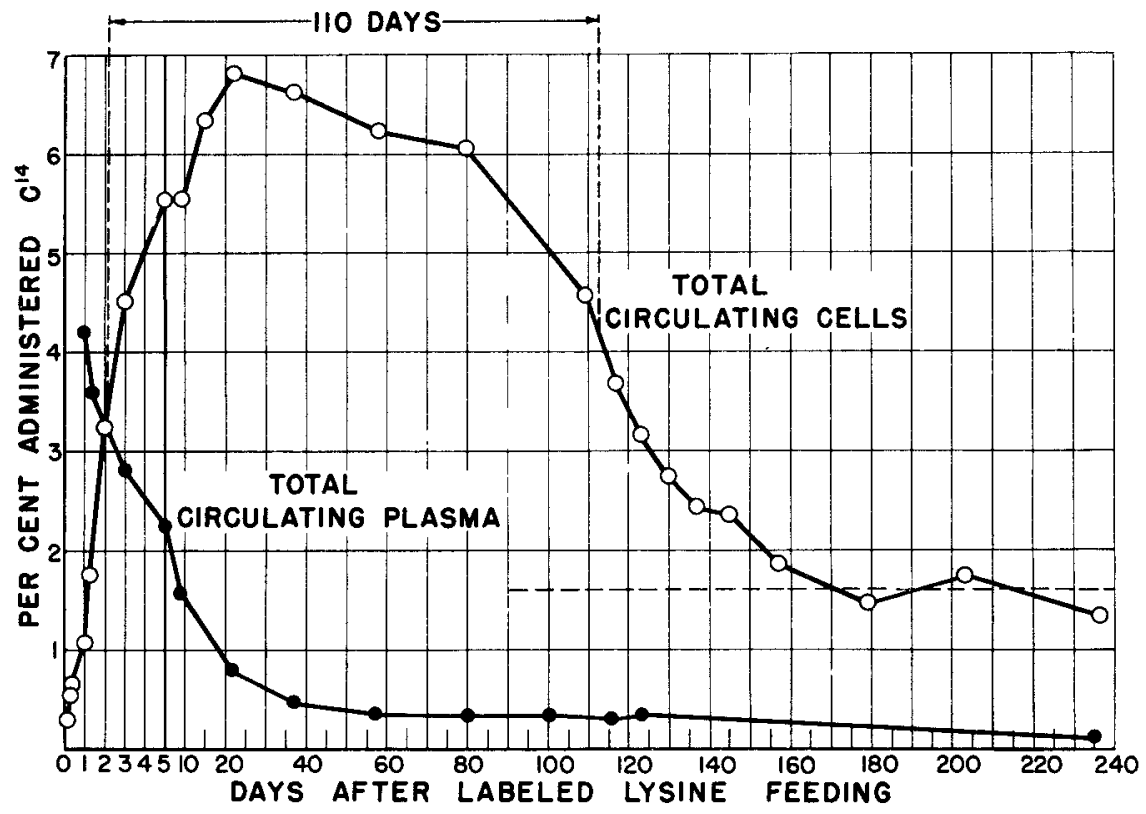

Fig. 2. Amount of $\mathrm{C}^{14}$ circulating in the plasma and cell Iractions of the blood. The approximate life span of the red cells is indicated. 
where the animal is deficient in circulating plasma proteins and on an adequate diet is constantly increasing the total amount of plasma proteins in circulation.

Fven when the total $\mathrm{c}^{1 / 4}$ content of the plasma proteins is decreasing, the newly formed plasma protelns presumably may contain $\mathrm{c}^{14}$ derived from labile body protein deposits, for example, liver. Therefore, the $\mathrm{c}^{14}$ plasma disappearance curve can be used only to set a lower limit for the average rate of turnover of plasma proteins. As can be seen in Fig. 2 , the $\mathrm{c}^{14}$ content of the plasma dropped from 4.4 to 2.2 per cent of the administared dose in a period of 5 days. On the assumption that this drop is logarithmic in nature, one can then compute that the average turnover of the plasma proteins incorporating $\mathrm{C}^{14}$ occurs in less than 10 days. Corrections for blood loss do not significantly change this figuro.

In contrast, as shown in Fig. 2, the $\mathrm{c}^{14}$ content of the pooled cellular elaments of the blood increased much more slowly so that a peak value was achieved in 5 days. About 80 days after the time of administration of tagged lysino the $\mathrm{c}^{14}$ content of the blood cells began to fall rapidly. It reached a new plateau at about 155 days. This new level corresponds, as can be noted from Fig. 1 , to a $\mathrm{c}^{14}$ content per gm, carbon approximately the same as the plasma level of the 60-150 day period. This suggests that the material initially formed in the blood cells from $\mathrm{C}^{14}$ has been mostly removed during the period of $80-150$ days and has been replaced from a pool with about the $\mathrm{C}^{1 / 4}$ content of plasma protein over this period. As shown in Fig. 2, about 110 days elapse between the point at which the $\mathrm{C}^{14}$ content of blood cells achieves 50 per cent of its maximum value and the point where the $\mathrm{c}^{14}$ content has decreased to a point midway between this maximum value and the plateau value beginning at 180 days. This period of 110 days clearly represents an approximation of the average time spent in red blood cells by 
$\mathrm{C}^{14}$ atoms.

Erythrocytes are the predominant cellular element of the blood. Present avallable evidence also indicates that the life span of the orythrocyte is many times that of the white blood cells. Therefore, the above data are predominantly an indication of the fate of $\mathrm{c}^{14}$ incorporated in the erythrocyte and show that the average time spent in erythrocytes by $\mathrm{C}^{14}$ administered to this dog as DL-lysine epsilon carbon is about 110 days. One type of red cell removal was through blood sampling. A correction for such orythrocyte loss suggests that had no blood samples been taken, the above figure would be increased at least to 115 days.

The above figure of about 215 days is close enough to the erythrocyte life span of about 124 days for the average dog, as determined by Hawkins and Thipple (4), to suggest that what is actually being measured here is the life span of the dog's erythrocytes. The proteins of the erythrocytes of this dog are therefore predominantly fixed and stable entities which, subsequent to the formation of the circulating red cell, do not undergo metabolic reconstruction or turnover during the circulatory life span of the cell; at least this experiment gives no evidence of turnover. This finding is similar to the result reported by Shemin and Rittenberg ( 8 ) in a study of hemin of the human erythrogyte carried out with $\mathrm{N}^{15}$ used as a labeling element.

Some further deductions from the data obtained on this dog are plausible. The circulatory lives of the erythrocytes labeled in this dog are not homogenous but fall predominantly in the range 80-150 days. The greatest rate of drop of $\mathrm{C}^{14}$ content of circulating cells occurs over the period 110-130 days after the labeled amino acid feeding. This period of 
time probably corresponds to the period of greatest bile pigment excretion reported by Hawkins and Thipple (4) in their red cell life span experiments using bile fistula hoalthy dogs.

One further conclusion appears reasonable. The drop of $\mathrm{c}^{14}$ concentration per $\mathrm{gm}$. carbon in circulating cells to a value at 160 days close to the plasma value of the 60-120 dey period suggests that the globin from destroyed cells is not used with great preferende in the formation of new cells. Rather it seems that the amino acids for new hemoglobin formation are drawn from a much larger labile body store of which at one time the plasma proteins with regard to $\mathrm{c}^{14}$ content seem to be an adequate sample. This is in harmong with the observations (6) that show that in a fasting dog nitrogen balance can be closely or actually sustained by dog hemoglobin given intraperitoneally.

\section{SURMARY AND CONCLUSIONS}

1. A dog, doubly depleted of blood cells and plasma proteins, was fed DL-lysine laboled with $\mathrm{C}^{14}$ in the epsilon carbon position. In the first 8 hours 28 per cent of the administered $c^{14}$ was excreted in the urine; in the first 72 hours, 35 per cent.

Twenty-four hours after feeding, 4.2 per cent of the fed $c^{14}$ was circulating in the plasma, decreasing to 1 per cent at the end of 17 days. The $\mathrm{C}^{14}$ content of the blood cells increased from 1 per cent at 24 hours to 5.5 per cent in 5 days and 6.8 per cent in 22 days.

2. Evidence based on the rate of decrease of the $\mathrm{C}^{14}$ content of circulating blood cells is presented indicating an average life of 115 days for the erythrocyte protein as an entity not interchanging with extracellular constituents. This closely corresponds to the life span of the dog erythrocyte, 112-133 days according to the best evidence otherwise 
available and indicates that this experiment has actually measured the Life span of the dog erythrocyte.

3. On the breakdown of blood erythrocytes the protein comprising them is not used preferentially for the formation of new erythrocytes.

We thank Dr. R. E. Masters, F. K. Millar and B. C. Adelman for valuable assistance in this work.

We are also indebted to Eli Lily and Company for aid in conducting this work.

\section{BIBLIOGRAPHY}

1. Bale, T. F., Kanuscript in preparation.

2. Gibson 2nd, J. G., Peacock, W. C., Seligman, A. M., and Sack, T., J. Clin. Inv., 1946, 25, 838.

3. Hahn, P. F., Ross, J. F., Bale, N. F., Balfour, T. M., and Thipple, G. H., J. Exp. Mod., 1942, 75, 221.

4. Hawkins, T. B., and Whipple, G. H., Am. J. Physiol., 1938, 122, 418.

5. Killor, L. L., Bale, W. F., Yuile, C. L., Kasters, R. E., Tishkoff, G. H., and Thipple, G. H., In Pross.

6. Killer, L. L., Robscheit-Robbins, F. S., and Whipple, G. H., J. Exp. Mod., 1945, 81, 405.

7. Olynyk, P., Camp, D. B., Griffith, A. M., Woislawski, S., and Helmkamp, R. W., J. Urg. Chem., 1948, 13, 405.

8. Shemin, D., and Rittenberg, D., J. Biol. Chem., 1946, 166, 627. 